\title{
Strategic Approach to the Regional Innovation System
}

\author{
Ostovskaya A.A. \\ Department of Public and Municipal Management \\ Institute of Economics and Management \\ V.I. Vernadsky Federal University \\ Simferopol, Russia \\ nastasy.ver@yandex.ua
}

\author{
Smirnova E.A. \\ Department of Business Finance and Insurance \\ Institute of Economics and Management, \\ V.I. Vernadsky Federal University \\ Simferopol, Russia \\ varwavska@mail.ru
}

\author{
Kozhukhova N.N. \\ Department of Management \\ Lomonosov Moscow State University, \\ Sevastopol, Russia \\ nadegda.red@gmail.com
}

\begin{abstract}
The study proves that at this stage, elaboration of an innovation-based strategy of national economic development is an objective necessity for all the industrialized countries. In such conditions, the high-priority task of the government regulation is to create favorable environment for the development of entrepreneurship and innovation activity. This research rationalizes that a workable solution to this problem may be the development of complex innovation strategies whereas such stages of strategic decision-making as forecasting and planning should include regional innovation system (RIS) building; the latter is expected to serve as a basic structural element of the investment and innovation policy of regional development.

Additionally, the research shows that stimulation of the innovation development in the regions requires engagement of the skilled professionals capable of creating a transformational system for the complete innovation process. A transition to the accumulation of the creative human capital is expected to be a stimulating factor for the innovation activity of the RIS subjects.

It has also been defined that successful development and implementation of the RIS strategy presuppose going through certain stages in a specific order; the stages are also presented in this study. The novelty of the suggested approach lies in using the resources available for RIS formation while paying particular attention to the mechanism of the RIS strategy development whereas both aspects are not currently given sufficient attention to in this area of studies.
\end{abstract}

Keywords-region; strategy; regional innovation system; innovation; innovation activity; stimulation.

\section{INTRODUCTION}

At the current stage of development, the national economic system is to a great extent subject to the global processes, which, therefore, enhances the role of the regions as the competitors. Thus, the capability to define the advantages and make efficient use of them in the conditions of such competition largely depends on the development of the regional innovation systems (RIS) which provide for the mutually beneficial relations between the stakeholders of the innovation activity and more efficient functioning of the regional production sphere within these systems.

The dynamics of conceptual changes in the innovation activity within different branches of national economy make developers focus more on strategic management [1]

Today, the nation faces the challenge of achieving the most effective use of the available potential of science, technology and industry in order to provide for the advantages in the sphere of technologies on the global market, which, hence, sets it on the course of innovation development. Some Russian researchers also maintain the idea that the innovation development is the only possible way of national development[2].

\section{LITERATURE REVIEW}

According to the modern internationally accepted approaches, innovation is defined as the final result of innovation activity materialized as a certain new or improved product launched onto the market or a new/advanced practically applied technological process [5].

Thus, it is worth mentioning that, for the time being, the development of the strategy of the innovation-based national economy remains an objective necessity for the countries with established industries, Russia not being an exception. Due to this, the government primarily faces the challenge of creating favorable conditions for the development of entrepreneurship and innovation activity, in other words, the challenge of creating environment that would stimulate innovation 
development, development strategies of the federal district, strategy of the socio-economic development of the Russian Federation, national strategy of the innovation development and digitalized economy programs as well as the strategies of industry development and strategies for the RIS stakeholders' development in the region;

- development and enhancement of the positive image of the region as a territory with favorable investment and innovation climate, with the emphasis on its attractiveness for investors.

\section{RESULTS}

The requirements above can be met on the condition that the innovation activity is stimulated in the regions, which can be achieved through hiring professionals capable of creating a breakthrough system of the innovation cycle in the short term providing for the high efficiency and competitiveness of the innovations in Russia:

$\mathrm{FR} \leftrightarrow \mathrm{AR} \leftrightarrow \mathrm{Dv} \leftrightarrow \mathrm{D} \leftrightarrow \mathrm{C} \leftrightarrow \mathrm{Ms} \leftrightarrow \mathrm{IP} \leftrightarrow \mathrm{M} \leftrightarrow \mathrm{S}$

where FR is fundamental research;

$\mathrm{AR}$ is applied research;

$\mathrm{D}$ is developments;

$\mathrm{D}$ is design;

$\mathrm{C}$ is construction;

Ms - mastering;

IP is industrial production;

$\mathrm{M}$ is marketing;

$\mathrm{S}$ is sales.

However, it should be taken into account that the current mechanism of the state regulation of innovation development has flaws when it comes to its methodological base, provided the conditions of the innovation activity development as well as the specifics of the scientific and technological potential remain uncertain $[10,11]$.

Due to this fact, successful development and implementation of the RIS strategy requires going through a number of definite stages that all together make up an algorithm of the RIS strategy development and implementation reflected in Table 1.

\section{TABLE I. STAGES OF THE RIS STRATEGy DEVELOPMENT} cooperation system based on the accepted and approved rules regulating such cooperation;

- analysis- based consolidation of the efforts and potential of all the RIS stakeholders having a shared goal (provided the analysis of the socio-economic data exposes the trends and priorities of the innovation development in the regions);

- elaboration of the road map which would reflect a plan of the consolidated actions performed by the RIS stakeholders and targeting innovation activity development in the region;

- investment and innovation vector of regional development coordinated with the strategies of regional

\begin{tabular}{|l|l|} 
Estimation of the & $\begin{array}{l}\text { At the organizational stage of the RIS strategy } \\
\text { development, its mechanism should be adapted in } \\
\text { order to provide for the multilevel participation } \\
\text { and its workability. At the regional level, it is } \\
\text { easy to notice the well-established cooperation } \\
\text { between the subjects of private and public sectors } \\
\text { and define their individual contribution into the } \\
\text { innovation development. Efficient regional } \\
\text { management in this field can be achieved, } \\
\text { providing the activities of the governmental } \\
\text { authorities, business, academic community and } \\
\text { general public are properly coordinated in the } \\
\text { process of the RIS strategy development and } \\
\text { implementation. The next step is starting a }\end{array}$ \\
\hline velopment
\end{tabular}


Another rational measure may be assigning certain quantitative and qualitative characteristics to the basic socioeconomic indices including those reflecting the parameters of innovation activity targeted by the federal and regional authorities as the results of designated activities. The adopted programs of action in the short and long term will give the local authorities an opportunity to fast track solutions to the vital (current) problems and coordinate the work of all the organs and stakeholders of the regional development while providing for the sustainable development according to its smart specialization. We hold the opinion that the primary goal at the regional level has to be the elaboration of the regional development concept as a representation system of the strategic choice, the objective and priorities of development and its basic provisions as per its separate constituents and means of goal accomplishment.

Acknowledgments: «The reported study was funded by RFBR according to the research project 19-010-00952».

\section{References}

3) Analysis of the This stage calls for a detailed diagnostics of the including the quality of $\quad$ in the region and for the estimation of the merits the interconnections and flaws of the innovation system (SWOT and between its subsystems PEST analyses). The analysis helps define and key stakeholders condition of the academic and innovation infrastructure and compare statistics; it also includes socio-economic and expert analysis of the survey results (the stakeholders of the RIS performing as the respondents of the survey on the innovation processes in the region and degree of cooperation between the key RIS stakeholders).

4) Setting goals, Foresight remains a relevant methodological tool objectives and in the RIS strategy development; successful measures of the RIS network-based development of multiple regions development strategy proves the power of unity when an agglomeration in conformity to the of numerous enterprises results from the chosen model application of the Foresight technologies, the latter also efficiently applied in innovation clustering and building network infrastructure.

5) Defining the Finding the optimal model of RIS and an optimal task sequence, adequate strategy of its development makes the the responsible parties key stage of the strategy implementation, and the mechanisms of influences the efficiency of the strategy as a monitoring and whole and defines the smart specialization of the evaluation $\quad$ region and priorities of its development depending on the resource, organizational and legal capacity of the regional management. Apart from exposing certain unique functions and assets, smart specialization also helps identify competitive advantages of each region and makes regional partners focus on the concept of the future development of the regional innovation system.

Source: elaborated by the authors; based on [12, 13, 14]

\section{CONCLUSION}

The proposed approach involves the available resources of RIS development while focusing on the mechanism of the RIS strategy development, which accounts for its originality as these issues mostly remain unaddressed in the contemporary research [15].
1] A.G. Lotariev, Improving the Mechanisms of State Regulation of Innovation Activities at the Regional Level. Mykolayiv: Petro Mohyla Black Sea National University. 2018.

[2] L.S. Markov, Theoretical and Methodological Fundations of the Cluster Approach in the Economy. Novosibirsk. 2014

[3] A.V. Markov, State Innovation Policy: Theoretical Basis and Mechanism of Implementation. Minsk: IOOO Pravo i ekonomika. 2005.

[4] M.P. Afanasiev, Program Budget. Moscow Infra-M publ. 2012.

[5] V.G. Fedorenko, The Principles of Management. Kyiv: Alerta. 2007.

[6] O.V. Kostenko, Regional Cluster Policy. Kirov Vyatskaya GSKhA publ. 2016.

[7] A.A. Kharin, I.L. Kolenskiy, N.N. Pushchenko, and et al., Management of Innovations. Moscow: Vysshaya shkola. 2003.

[8] S.A. Gorblyuk, Mechanisms of Establishing Regional Innovation Systems. Dissertation, Kyiv: The National Academy for Public Administration under the President of Ukraine. 2017.

[9] Alexsandr S. Kuznetsov, Russian Professor's meeting. Russian Journal of Physical Education and Sport. 2019, 14(1), pp. 17-22. DOI: 10.14526/2070-4798-2019-14-1-18-24

[10] V.V. Tarasenko, "On state support of pilot innovative territorial clusters," Available at: http://csrnw.ru/files/csr/file_content_1303.pdf

[11] M. Glukhova, "Clusters - whether they are Russian economy Promishlennik Rossii," 2012. Available at: http_//www.promros.ru/magazine/2012/oct/mariya_gluhova_klastery_n uzhny_li_oni_rossijskoj_ekonomike.phtml

[12] I. Makarova, K. Shubenkova and, L. Gabsalikhova, "Analysis of the city transport system's development strategy design principles with account of risks and specific features of spatial development," Transport Problems, 12 (1).2017, pp.76-78.

[13] I. Makarova, K. Shubenkova, P. Buyvol and et al., "Interaction between education and business in digital era," Proceedings of the 2018 IEEE Industrial Cyber-Physical Systems, ICPS. 2018, pp. 503-508.

[14] J. Skonieczny and A. Świda, "Foresight i benchmarking jako narzędzia wywiadowcze wykorzystywane w kreowaniu polityki rozwoju regionów europejskich,” in Journal, vol. ,Warszawa : Difin. 2006, pp. 65-72.

[15] A.G. Afonina Economic Content and the Mechanism of Management of Development of Clusters in Regional Economy. Perm. 2012. 